\title{
Pancasila Sebagai Pedoman Kehidupan Bagi Generasi Muda
}

\author{
Muhammad Bayu Al Ghifari \\ Universitas Pembangunan Nasional "Veteran" Yogyakarta \\ 114210087@student.upnyk.ac.id
}

\begin{abstract}
ABSTRAK
Penelitian ini bertujuan untuk menjabarkan tentang pandangan generasi muda Indonesia terhadap adanya Pancasila yang dilihat sebagai ideologi bangsa Indonesia. Keberadaan Pancasila adalah sesuatu yang sangat berharga bagi bangsa Indonesia terutama bagi generasi muda Indonesia yang kedepannya akan melanjutkan tongkat estafet perjuangan untuk mewujudkan Indonesia yang maju dan sejahtera serta merealisasikan cita - cita para pendahulu. Tetapi di masa sekarang, para generasi muda Indonesia sudah tidak ingin lagi memegang teguh nilai - nilai Pancasila sebagai ideologi negara lalu menerapkannya di kehidupan sehari - hari. Metode yang digunakan pada penelitian ini merupakan metode dengan pendekatan kualitatif. Data yangakan kemudian digunakan dalam penelitian ini diperoleh dari jurnal ilmiah, berita, dan studi hasil penelitian sebelumnya. Analisis data yang digunakan dalam penelitian ini menggunakan analisis deskriptif analitis. Hasil dari penelitian ini menunjukan bahwa para generasi muda sebenarnya memiliki pengetahuan tentang pengamalan Pancasila tetapi kurang pada pelaksanaannya. Para generasi muda masih belum bisa melaksanakan dan menghayati nilai - nilai Pancasila karena terdistraksi oleh berbagai macam persoalan bangsa yang tentunya tidak sejalan dengan nilai luhur Pancasila.
\end{abstract}

Kata Kunci: Pancasila, Bela Negara, Kewarganegaraan, Generasi Muda.

\begin{abstract}
This study aims to describe the views of the younger generation of Indonesia on the existence of Pancasila which is seen as the ideology of the Indonesian nation. The existence of Pancasila is something that is very valuable for the Indonesian people, especially for the younger generation of Indonesia who in the future will continue the baton of struggle to realize an advanced and prosperous Indonesia and realize the ideals of their predecessors. But nowadays, the younger generation of Indonesia no longer wants to hold fast to the values of Pancasila as the state ideology and then apply them in their daily lives. The method used in this study is a method with a qualitative approach. The data that will be used in this study were obtained from scientific journals, news, and studies of previous research results. Analysis of the data used in this study using analytical descriptive analysis. The results of this study indicate that the younger generation actually has knowledge about the practice of Pancasila but lacks in its implementation. The younger generation is still unable to implement and live up to the values of Pancasila because they are distracted by various kinds of national problems which are certainly not in line with the noble values of Pancasila.
\end{abstract}

Keywords: Pancasila, National Ressilience, Citizenship, Young Generation. 


\section{PENDAHULUAN}

Pancasila merupakan ideologi bangsa Indonesia dan merupakan anugerah terbesar yang diberikan oleh Tuhan pada bangsa kita tercinta ini. Dengan adanya Pancasila, diharapkan Indonesia bisa merealisasikan cita - cita bangsa agar lebih maju dan rakyatnya sejahtera. Lebih dari itu, Indonesia memiliki misi dan cita - cita yang lebih kompleks apalagi pada momen perumusan dasar negara, Indonesia adalah negara yang baru saja merdeka dan sangat rentan akan guncangan dan terpaan cobaan baik dari internal maupun dari eksternal bangsa ini sendiri. Oleh karena itu, Indonesia sangat membutuhkan sebuah ideologi atau dasar negara yang berasal atau berakar dari bangsa Indonesia itu sendiri. Dari hal tersebut, kita tahu bahwa keberadaan Pancasila sangat penting bagi bangsa Indonesia apalagi untuk generasi mudanya sebagai penerus perjuangan bangsa ke arah yang lebih cemerlang.

Umumnya, generasi muda mendapatkan pengetahuan pertamanya tentang pancasila ketika mengenyam pendidikan sekolah dasar. Setelah mendapatkannya di sekolah dasar, kemudian mereka mendapatkan kembali pengetahuan tentang Pancasila di sekolah mengengah sampai perkuliahan. Saat itulah, pikiran serat nurani mereka dibentuk pengetahuannya tentang Pancasila. Umumnya, Pendidikan tentang Pancasila dan kewarganegaraan ketika sekolah hanya sebatas hafalan dan hanya sebagai materi semata. Hal ini yang membuat kekhawatiran kita muncul akan memudarnya pengamalan nilai - nilai luhur Pancasila di setiap sendi - sendi kehidupan kita. Seperti yang kita ketahui, bahwa Pancasila sangatlah penting dan memiliki peran yang sangat fundamental untuk bangsa Indonesia. Tanpa ideologi dan tanpa pengamalannya, perjalanan sebuah negara untuk mencapai kemajuan dan kesejahteraan akan berjalan lamban dan bahkan tidak berjalan sama sekali yang akhirnya akan menghadirkan konflik didalamnya.

Tulisan ini akan membahas tentang bagaimana generasi muda memperlakukan Pancasila sebagai 
dasar negara dan ideologi bangsa di kehidupan sehari - hari sebagai masyarakat yang hidup berbangsa dan bernegara. Pengamalan Pancasila merupakan sesuatu yang penting bagi keberlangsungan hidup berbangsa dan bernegara. Karena untuk ikut serta dalam perkembangan dunia setiap bangsa dan Negara mau tidak mau harus selalu siap untuk menghadapi segala macam bentuk ancaman serta resiko. Salah satu resiko tersebut ialah yang dibawa oleh dampak globalisasi serta modernisasi saat ini, begitu juga dengan generasi muda saat ini yang sejatinya hamper semua dari mereka tengah hidup dalam kemajuan teknologi yang membuat seakanakan hidup ini dibuat tanpa tahu dengan ada nya batasan sama sekali (Rahmat\&Marzuki， 2018: 186)). Keselamatan suatu bangsa dan Negara merupakan suatu kondisi yang harus terwujud dan tidak dapat ditawar apabila bangsa dan Negara ingin bertahan hidup sebagai suatu Negara. Untuk menjaga keselamatan bangsa dan Negara dibutuhkan suatu upaya yaitu bela Negara (Budiyono, 2017: 55-63). Maka dari situ tidak hanya diperlukan pengetahuan tetapi juga pemahaman kaum muda tentang Negara dan nilai nilai, serta filosofi kehidupan bangsa Indonesia yang sudah sangat memadai yaitu Pancasila. Seperti dengan demonstrasi atau menyampaikan gagasan di muka umum yang merupakan suatu hak mutlak tentang adanya kebebasan bagi seluruh warga Negara Indonesia, Untuk itu, masalah-masalah yang muncul seiring dengan perkembangan zaman tentang Negara, masyarakat, dan generasi muda sangat perlu utuk diketahui secara lebih terbuka dan menyeluruh di kalangan generasi muda.

\section{METODE}

Pada tulisan ini, meneliti dengan pendekatan kualitatif dimana meneliti generasi muda dengan pertanyaan - pertanyaan seputar Pancasila di era globalisasi sekarang ini. Prosedur yang dilakukan antara lain mengumpulkan data - data dari berbagai jurnal dan data dari jawaban - jawaban para narasumber yang diwawancarai menggunakan aplikasi 
Whatsapp kemudian mengelompokkan data tersebut ke dalam jenis penelitian kualitatif.

\section{HASIL DAN PEMBAHASAN}

Pada penelitian ini, melibatkan pandangan yang diutarakan oleh para generasi muda tentang apa itu Pancasila? Pancasila adalah ideologi negara dimana Pancasila merupakan akal pikiran bagi Indonesia untuk menuju pintu kesejahteraan (Nurul, 2021). Pancasila adalah pedoman atau prinsip kita dalam tata laku berbangsa dan bernegara yang sesuai dengan moral bangsa (Nida, 2021). Pancasila adalah dasar negara Indonesia (Mambe, 2021). Pancasila merupakan dasar negara dimana diciptakan dari nilai - nilai luhuru kemajemukan Indonesia agar keberlangsungan hidup bangsa dapat terjaga dengan baik kedepannya (Aris, 2021). Pancasila adalah ideologi bagi bangsa Indonesia yang harus dijunjung tinggi. Pancasila ialah terdiri dari 5 sila yang pada setiap sila nya mengandung makna makna filosofis (Kasman, 2021). Pancasila adalah dasar negara yang memuat segala pikiran bangsa Indonesia yang sangat majemuk ini, yang memiliki perbedanan dari ujunga barat sampai ujung timur, utara ke salatan. Dan semua itu tertuang di dalam satu ideologi yaitu Pancasila sebagai bintang penuntun bangsa Indonesia menuju tujuan yang lebih baik (Torik, 2021). Lalu, apakah generasi muda sudah mengamalkan nilai - nilai Pancasila di kehidupannya? Ada beberapa nilai yang mungkin sudah terlaksana yaitu nilai ketuhanan, kemanusiaan dan persatuan (Nurul, 2021). Masih belum terlaksana dan belum mengamalkannya, karena memang belum ada contoh yang konkrit dari pelaksana pemerintah yang bisa dijadikan panutan sebab masyarakat pasti akan meneladani sesuatu dari pemimpinnya (Sakti, 2021). Lalu, apakah perilaku pelaksana pemerintah sangat berpengaruh terhadap pengamalan Pancasila oleh masyarakat? Perilaku pelaksana pemerintah sangat penting karena bagaimanapun juga mereka adalah pemimpin yang dimana sesuatu yang baik harus dapat dipetik dari mereka. Sekarang sebaliknya, mereka malah 
sering kali melakukan hal - hal yang bertentangan dengan nilai - nilai Pancasila (Yunita, 2021). Sangat berpengaruh terhadap mentalitas masyarakat apalagi untuk masyarakat yang berpendidikan rendah. Sampai saat ini, mereka tidak berperilaku yang sesuai dengan nilai - nilai Pancasila sehingga membuat mentalitas msyarakat rusak (Yuan, 2021).

Pancasila yang menjadi
ideologi, dasar negara, serta
pedoman hidup untuk penuntun bangsa Indonesia ke arah dan tujuan yang lebih baik yang sesuai dengan cita - cita bangsa. Dari beberapa pertanyaan diatas, menunjukkan bahwa generasi muda sudah tahu apa itu Pancasila secara harfiah dan pengertian. Umumnya, mereka mendapatkan pengetahuan tersebut Ketika sedang mengenyam Pendidikan di bangku sekolah formal 12 tahun dan sampai kuliah pun tetap mendapatkannya. Dan sebagai warga Negara yang patuh kita diharapkan faham akan hak dan kewajiban yang kita miliki yang sudah sesuai dengan peraturan perundang-undangan yang berlandaskan atas kesadaran tanpa adanya paksaan dari orang lain. Dimana setiap manusia harus memanusiakan manusia. Karena. Pada hakikatnya tidak ada satu pun manusia yang dapat hidup tanpa berdampingan dengan manusia lain, sehingga dibutuhkan kerjasama yang diwujudkan dalam kehidupan nyata yaitu 'persatuan Indonesia.'

generasi muda harus dituntut untuk ikut serta berperan aktif dan berpartisipasi dalam kegiatan berbangsa dan bernegara, seperti misalnya; mengikuti pesta demokrasi, menyerukan gagasan tentang penyelesaian konflik dan ikut serta dalam melestarikan budaya nilai-nilai luhur yang dianut dalam Pancasila dengan upaya bahwa generasi muda menjadi tokoh utama untuk menjadikan bangsa Indonesia sebagai bangsa yang maju dan dapat menjadi cerminan bangsa dan Negara melalui pengadaan perubahanperubahan dalam lingkungan masyarakat, baik secara nasional maupun daerah menuju ke arah yang lebih baik. Maka tantangan dalam bentuk apapun yang akan dihadapi dikemudian hari terhadap Pancasila Indonesia karena terciptanya 
perbedaan pendapat dari warga Negara Indonesia dapat dihadapi secara positif dan dilakukan bersama-sama atas asas Bhinneka Tunggal Ika.

\section{SIMPULAN}

Pancasila merupakan ideologi dan dasar negara yang mengandung segenap pikiran bangsa Indonesia yang majemuk dan beragam. Dimulai dari Sabang sampai Merauke, Indonesia adalah negara dengan kebudayaan yang sangat beragam. Tidak hanya kebudayaan, bahasa daerah yang digunakan juga sangat beragam. Oleh karena itu, Pancasila oleh generasi muda dianggap sebagai salah satu alat pemersatu bangsa. Pancasila juga sebagai satu kesatuan dasar negara, filsafat negara, pandangan hidup serta pedoman hidup negara dalam mewujudkan segala cita dan cinta rakyatnya. Pancasila tidak hanya sebatas pengertian secara harfiah, lebih dari itu, Pancasila dapat dikatakan sebagai alat pembangun bangsa dan alat kekuasaan bangsa dimana segala macam tingkah laku masyarakatnya baik itu masyarakat biasa maupun aparat negara hendaknya berpedoman terhadap Pancasila dan Pancasila sebagai pengahalang dan yang berkuasa Ketika ingin melakukan hal - hal yang bertentangan dengan Pancasila. Pancasila juga tidak lekang oleh waktu dan dapat dipakai di semua zaman. Apalagi di era globalisasi sekarang ini yang melanda generasi muda, menjadikan mereka semakin tidak mempunyai Batasan terhadap apapun. Pancasila harus bisa diamalkan di dalam seluruh aspek kehidupan sehari - hari demi menanggulangi pudarnya nilai - nilai Pancasila itu sendiri. Generasi mudalah yang harus memperjuangkan itu semua demi keberlangsungan bangsa dan negara mengingat tantangan zaman yang semakin dahsyat sekarang ini.

\section{DAFTAR PUSTAKA}

Rahmat Wijayanto J. \& Marzuki.(2018). Keselamatan Suatu Bangsa dan Negara dengan Upaya Bela Negara: 186.

http://journal2.um.ac.id/index .php/j ppk. Vol. 3, No. 2, Desember 2018 
Budiyono.(2017). Memperkokoh ideologi Negara Pancasila melalui bela Negara. Citizenship Journal

Yudistira.(2016). "Aktualisasi \& Implementasi Nilai-Nilai Pancasila Dalam Menumbuhkan Kembangkan Karakter Bangsa. In Seminar Nasional Hukum. Vol. 2, pp. 421-436

Roberto Salu.(2019). "Pancasila dan Tantangan Masa Kini". Elementary Jornal. Vol. 2, No. 1, Juni 2019

M. Sastrapratdja, 2001, Pancasila sebagai visi dan referensi kritik sosial, Penerbit Universitas Sanata Dharma, Yogyakarta

Darmaputera, Eka, 1989, Pancasila: Identitas dan Integritas Bangsa Indonesia, Jakarta: Gunung Mulia,

Suwarno, P.J., 1993, Pancasila Budaya Bangsa Indonesia (Penelitian Pancasila dengan Pendekatan Historis, Filosofis, dan Sosio-Yuridis Kenegaraan), Yogyakarta: Kanisius

Adhayanto, O. (2015). Implementasi Nilai-Nilai Pancasila Sebagai Dasar Negara Dalam Pembentukkan Peraturan Perundang-Undangan. Jurnal Ilmu Hukum, 6(2), 166-174.

Ambiro Puji Asmaroini.(2017). Menjaga Eksistensi Pancasila dan penerapanya Bagi Masyarakat di Era Globalisasi. Journal Pancasila and Citizenship. Vol. 1, No. 2, Januari 2017

Efendi, Y., \& Sa'diyah, H. (2020). Penerapan Nilai-Nilai Pancasila Dalam Lembaga Pendidikan. JPK (Jurnal
Pancasila dan Kewarganegaraan), 5(1), 5465.

\section{UCAPAN TERIMA KASIH}

Dengan selesainya penulisan jurnal ini sebagai, penulis menyampaikan terima kasih kepada Allah SWT yang telah memberikan nikmat dan hidayah-NYA sehingga penulis dapat menyelesaikan penelitian ini. Terima kasih pula kepada kedua orang tua penulis yang selalu memberi dukungan penuh kepada penulis. Dan terima kasih pula kepada Bapak Lestanta Budiman selaku Dosen Pengampu Mata Kuliah

Pendidikan Pancasila.

\section{TENTANG PENULIS}

Muhammad Bayu Al Ghifari, putra pertama dari pasangan Syatriadi dan Murniati. Lahir di Dompu, 12 April 2002. Ia menempuh Pendidikan sekolah dasar dan menengahnya di Kabupaten Dompu, NTB. Saat ini, sebagai mahasiswa di Universitas Pembangunan Nasional "Veteran" Yogayakarta. 